\section{Fra barn til voksen}

Overgangsfasen fra barn til voksen er en utfordring for de fleste. Særlig vanskelig er den for dem som er sårbare i utgangspunktet som pasienter med sammensatt kronisk sykdom. Blant disse finner vi mennesker med cerebral parese, med komorbide tilstander og utviklingshemning, det vil si for dem som tilhører habiliteringstjenestens målgruppe.

Barn og unge med kroniske sykdommer og multifunksjonshemning har ofte en helhetlig og tett oppfølging ved barnehabilitering og barneavdelinger. Mens helseoppfølgingen i førstelinjetjenesten som regel blir ivaretatt av fastlegen, har barnehabiliteringen i noen tilfeller nærmest overtatt denne funksjonen, særlig for barn/ungdom med større funksjonsnedsettelser. Fastlegen blir da lite involvert i denne behandlingen og kjenner pasienten i liten grad. Når disse pasientene fyller 18 år, er oppfølgingen oftest langt mer fragmentert. Fra å ha mulighet til å ta direkte kontakt med spesialisthelsetjenesten/barneavdelingen (åpen retur), må de etter fylte 18 år via fastlegen henvises til ulike spesialister etter behov, slik som alle andre.

Kjersti Ramstad og medarbeidere gir i dette nummer av Tidsskriftet en oversikt over utfordringer knyttet til overgangen som pasient fra barn til voksen, eksemplifisert ved ungdom med cerebral parese (1). Denne populasjonsbaserte studien styrker antakelsen om at det er mangler når det gjelder lokal forankring og koordinering av tilbudet $o g$ at tilbudet er geografisk ulikt fordelt.

Voksenhabilitering i spesialisthelsetjenesten skal tilby utredning og diagnostisering samt behandling og oppfølging av definerte pasientgrupper med medfødte og/eller tidlig ervervede nevrologiske funksjonsforstyrrelser og/eller utviklingsforstyrrelser. Til tross for Helsedirektoratets anbefaling om et standardisert tilbud, er tjenesten svært ulikt organisert i de forskjellige deler av landet. Det er for eksempel anbefalt en minimumsbemanning av lege, psykolog og vernepleier i voksenhabiliteringen i spesialisthelsetjenesten (2), men det er per i dag ikke mer enn vel 31 legeårsverk totalt, med stillingsbrøker på $10-20 \%$ noen steder (3). For voksne med cerebral parese vil dette i noen grad bli kompensert av oppfølging $i$ andre deler av spesialisthelsetjenesten, som nevrologisk, ortopedisk og fysikalsk medisin. For andre sykdomsgrupper (syndromer, utviklingshemning, autisme) vil en tilknytning til voksenhabiliteringen være viktig på grunn av spesifikke problemstillinger knyttet til grunnlidelsen.

Fastlegen er spesielt viktig for unge med cerebral parese som ikke ønsker oppfølging i spesialisthelsetjenesten. Etter å ha vært fulgt tett med trening og fysioterapi i mange år er det noen som vil være uavhengige. Det er del av selvstendiggjøringen i starten av voksenlivet - man vil legge mindre vekt på helsemessige utfordringer, slik som mange andre unge voksne. Imidlertid er vår erfaring at det i denne sårbare livsfasen ofte vil oppstå spørsmål av psykososial art - som det å leve med kronisk sykdom og ønsket om å være «normal» og bli inkludert. Da vil det være viktig å holde kontakt med pasienten for å kunne fange opp eventuelle problemer tidlig.

Ved Oslo universitetssykehus, Ullevål, har barne- og voksenhabiliteringen god erfaring med å avholde overgangssamarbeidsmøte med fastlege, representanter fra førstelinjetjenesten, pårørende og pasient i god tid før denne fyller 18 år. Her forberedes de endringer som inntreffer etter denne dagen, både når det gjelder helseoppfølging i spesialisthelsetjenesten, trygdeytelser og eventuell endring av koordinator i bydel/kommune. Vi forsikrer oss om at en fullstendig kartlegging er gjort og avtaler som regel en avsluttende kontroll i barnehelsetjenesten. Videre oppfølging i voksenhelsetjenesten vurderes ut fra den enkeltes behov. For noen, særlig de pårørende, medfører dette ofte store endringer og usikkerhet, og fastlegen kan her spille en viktig rolle. Vi ser da også en positiv tendens når det gjelder oppfølging og kontakt med fastlegen sammenliknet med slik det var for bare noen få år siden.

Personer med kronisk sykdom har mange lovpålagte rettigheter, men erfaringsmessig blir disse i varierende grad innfridd. Oppfølging av dem som har behov for sammensatte helse- og omsorgstjenester over tid krever tverrfaglig samarbeid på flere arenaer. En individuell plan (IP) gir mulighet for å planlegge og få en oversikt over en slik oppfølging, det være seg anbefalte helseundersøkelser, overgang til arbeid/dagtilbud eller egen bolig. Individuell plan er et nyttig verktøy dersom den blir brukt etter intensjonen. Dessverre blir det ofte kun et papir, siden ønskede tiltak ikke blir gjennomført (rettighet, men ingen rett). En individuell plan er, som Ramstad og medarbeidere antyder, ingen god indikator på kvalitetssikret ivaretakelse av den enkeltes rettigheter og behov. Det er derfor ønskelig at validiteten av individuell plan styrkes og knyttes opp mot lovfestede rettigheter.

Utvalget i studien er representativt for ti fylker i Sørøst-Norge, med noe overrepresentasjon fra rurale strøk og underrepresentasjon av mennesker med flerkulturell bakgrunn (18\%). I Oslo har flerkulturelle representert vel $30 \%$ av henvisningsmassen i flere år. Det vil være av interesse å kartlegge denne pasientgruppen ytterligere, da det klinisk erfaringsmessig kan være særlige utfordringer knyttet til oppfølging av multifunksjonshemmede med innvandrerbakgrunn.

Ungdom som har vært fulgt ved barnehabiliteringen i spesialisthelsetjenesten bør forankres lokalt, og fastlegen bør ha en sentral rolle. Det bør være utarbeidet et strukturert overgangsprogram for dem som vil trenge habilitering i voksen alder, gjerne med sjekklister slik som for andre unge med kronisk sykdom (4). Spesielt der hvor det er komorbiditet, bør det defineres pasientforløp med tverrfaglig planlegging av overgangen fra barne- til voksenhelsetjenesten i god tid før pasienten fyller 18 år, og fastlegen bør inkluderes.

\section{Kathrine J. Haggag}

kathrine.haggag@ous-hf.no

Kathrine J. Haggag (f. 1958) er spesialist i nevrologi og seksjonsoverlege ved Avdeling for nevrohabilitering, Oslo universitetssykehus, Ullevål.

\footnotetext{
Litteratur

1. Ramstad K, Jahnsen RB, Diseth TH. Ungdom med cerebral parese og deres kontakt med fastlege og habiliteringstjeneste. Tidsskr Nor Legeforen 2015; 135: $429-33$

2. IS-1739, juni 2009. https://helsedirektoratet.no/publikasjoner/ habiliteringstjenesten-for-voksne-i-spesialisthelsetjenesten-/ (16.2.2015) 3. Kartlegging av faggrupper $\mathrm{i}$ habilitering. www.habilitering.no/?page_id=590 (16.2.2015).

4. Prosjekt ungdomsmedisin. Akershus universitetssykehus. www.ahus.no/ omoss_/avdelinger_/barne--og-ungdomsklinikken_/ungdomsmedisin_/ Brosjyrer_/Sider/Brosjyrer.aspx (16.2.2015).
}

Podkast på www.tidsskriftet.no 